\title{
Pengamatan Laju Penyakit White Syndrome Pada Montipora sp. Di Pulau Pramuka, Taman Nasional Laut Kepulauan Seribu, DKI Jakarta
}

\author{
Abdur Rosyid a, Oktiyas Muzaky Luthfi a* \\ aProgram Studi Ilmu Kelautan, Fakultas Perikanan dan Ilmu Kelautan, Universitas Brawijaya, Malang, Jawa Timur, Indonesia \\ *Penulis koresponden. Tel.: +62-813-901-067-90 \\ Alamat e-mail: omuzakyl@ub.ac.id
}

Diterima (received) 16 November 2017; disetujui (accepted) 3 Februari 2018; tersedia secara online (available online) 5 Februari 2018

\begin{abstract}
Coral disease now became main factor of coral degradation in the world. There is still a few report about coral disease in Kepulauan Seribu Marine National Park (TNKPS) include of white syndrome (WS) in Montipora sp. WS was characterized by white area on coral surface at several stages. WS had caused coral tissue loss and leaved bare $\mathrm{CaCO}_{3}$ skeleton that was caused by pathogenic Vibrio coralliitycus associated with other microorganisms. In this study the progress of WS calculated by measurement of the distances of WS that moved from diseased to healty coral surface. All calculations was performed used ImageJ Software. Our result showed that WS progression rate in first week was $9.06 \mathrm{~cm}^{2}$ and the second week was $2.37 \mathrm{~cm}^{2}$. Total coral tissue mortality was $12.03 \%$ for 2 weeks.
\end{abstract}

Keywords:hard coral; ImageJ; Vibrio coralliitycus; tissue loss; $\mathrm{CaCO}_{3}$

\begin{abstract}
Abstrak
Penyakit karang saat ini telah menjadi faktor utama kerusakan karang di dunia. Saat ini masih sedikit laporan mengenai penyakit karang di Taman Nasional Kepulauan Seribu (TNKPS) khususnya penyakit white syndrome (WS) pada karang Montipora sp. WS merupakan penyakit yang menimbulkan adanya area berwarna putih pada permukaan karang. WS menyebabkan hilangnya jaringan (tissue loss) pada karang dan menyisakan skeleton berupa $\mathrm{CaCO}_{3}$ yang disebabkan karena adanya bakteri pathogen Vibrio coralliitycus yang berasosiasi dengan berbagai jenis mikroorganisme lainnya. Penelitian ini menghitung laju penyakit dengan mengukur jarak WS yang bergerak dari bagian yang sakit ke bagian yang sehat. Perhitungan dilakukan menggunakan perangkat lunak ImageJ. Hasil penelitian ini menunjukkan laju pertumbuhan penyakit sebesar $9.06 \mathrm{~cm}^{2}$ pada minggu pertama dan $2.37 \mathrm{~cm}^{2}$ pada minggu kedua. Mortalitas jaringan karang sebesar 12.03\% selama 2 minggu.
\end{abstract}

Kata Kunci:karang keras; Image J; Vibrio coralliitycus;kehilanganjaringanhidup; $\mathrm{CaCO}_{3}$

\section{Pendahuluan}

Kondisi terumbu karangsaat ini mengalami degradasi yang berfluaktuatif, tercatat pada 1998 kerusakan karang akibat mass bleaching telah menurunkan produktifitas terumbu karang (Pandolfi et al., 2003; Bryant et al., 1998). Kerusakan terumbu karang yang terjadi ditandai oleh menurunnya jumlah hewan-hewan yang berasosiasi dengan ekosistem terumbu karang. Kualitas perairan juga ikut serta dalam mempengaruhi keadaan ekosistem terumbu karang. Terumbu karang membutuhkan kualitas perairan yang bagus untuk menunjang kehidupannya seperti perairan yang jernih, suhu yang hangat, salinitas yang stabil, dan mendapatkan cahaya (Soenardjo, 2013).

Menurut hasil penelitian Chou (2000), sebanyak $40 \%$ terumbu karang di Indonesia termasuk dalam kategori rusak dengan tutupan karang hidup dibawah $25 \%$, sedangkan terumbu karang dengan tutupan karang lebih dari 50\% hanya tersisa $29 \%$ Indonesia. Penelitian pada 15 lokasi di perairan 
laut Jawa, Sulawesi dan Ambon menunjukkan bahwa kerusakan terumbu karang akibat limbah domestik, sedimentasi dan polusi dari sector industry telah menurunkan diversitas penyusun terumbu karang sebesar 10-60\% (Edinger et al., 1998). Kerusakan terumbu karang yang disebabkan faktor alamiah juga telah dilaporkan di perairan Sulawesi, dimana pada tahun 2005 hanya ditemukan 2 jenis penyakit karang yaitu white syndrome dan growth anomalies, namun 2 tahun kemudian ditemukan 4 jenis penyakit karang yaitu white syndrome, Porites ulcerative white spot disease, growth anomalies dan black band disease (Haapkylä et al., 2009)

Taman Nasional Laut Kepulauan Seribu berjarak $45 \mathrm{~km}$ di utara jakarta, Indonesia. Taman Nasional Laut Kepulauan Seribu (TNKPS) memiliki luas sebesar 108.000 ha (Amanah, 2004). Sebagian besar wilayah taman nasional difokuskan untuk menanggulangi polusi dikarenakan TNKPS berada dekat dengan ibukota DKI Jakarta yang memiliki populasi penduduk sampai 9.99 juta (BPS, 2013). Buangan limbah air dan kotoran adalah pencemar utama yang dibawa oleh 13 sungai menuju teluk Jakarta (Rochyatun dan Rozak, 2007). Pencemar lainnya adalah tumpahan minyak yang terjadi beberapa kali dan menggangu kesehatan terumbu karang. Berdasarkan pengamatan jangka Panjang dari 2003-2007 didapatkan sebanyak 2,63\% karang di sebelah selatan Kepulauan Seribu telah terkena penyakit (Estradivari et al., 2009; Johan et al., 2015).

Kondisi terumbu karang global saat ini sedang terancam (Johan et al., 2015). Infeksi penyakit pada karang telah mempengaruhi kondisi terumbu karang global dan menjadi salah satu faktor utama yang terdegradasinya tutupan karang (Miller et al., 2009). Aspek ekologi terumbu karang sangat dibutuhkan untuk memahami penyakit yang terjadi pada karang. Khususnya munculnya penyakit yang dapat menyebabkan kematian seperti penyakit White Syndrome (Johan et al., 2015) Penyakit yang menyerang hewan karang umumnya terjadi akibat kondisi fisiologis yang lemah setelah terjadinya bleaching dan atau dalam kondisi rentan akibat kompetisi dengan pertumbuhan algae yang sangat cepat (Abrar et al., 2012).

White Syndrome (WS) adalah jenis penyakit yang pola persebarannya tidak memiliki ciri khas. Fenomena tissue loss dari WS berbeda pola dengan white band dan white plague. Bagian karang yang telah kehilangan jaringan terlihat jelas hanya tinggal kerangka $\mathrm{CaCO}_{3}$. Luka yang diakibatkan penyakit ini terlihat putih menyisakan kerangka $\mathrm{CaCO}_{3}$ yang tergradasi hingga warna coklat. WS terlihat mirip dengan bleaching namun disertai dengan fenomena Tissue Loss (Raymundo et al., 2008).

White Syndrome (WS) adalah jenis penyakit yang umum dijumpai menginfeksi karang jenis Montipora spp. dan Acropora spp. Johan et al., (2015), melaporkan di daerah kepulauan seribu karang yang paling banyak menunjukkan tandatanda adanya white syndrome terdapat di selatan Pulau Pramuka, Pulau Kelapa, dan Pulau Karang Bongkok. WS dapat ditemukan menginfeksi karang pada semua musim dengan kelimpahan tertinggi pada musim kemarau dan kelimpahan terendah pada musim hujan. Kelimpahan WS yang menginfeksi karang terlihat tidak adanya perbedaan yang signifikan antara setiap musimnya (Johan et al., 2015). Ushijima et al. (2012), melakukan pengamatan terhadap Montipora yang terkena white syndrome akut dan menemukan adanya Vibrio coralliilytycus yang berperan sebagai agen penyakit. Pada tahun 2014 ditemukan Vibrio owensii pada Montipora yang terkena white syndrome yang berlokasi di Hawaii (Ushijima et al., 2014).

Penelitian ini bertujuan untuk mengetahui laju infeksi penyakit white syndromepada terumbu karang Montipora sp di Pulau Pramuka, Kepulauan Seribu, DKI Jakarta.

\section{Metode Penelitian}

Pengamatan dilakukan di perairan pulau Pramuka bagian barat. Peta lokasi pengamatan ditunjukkan Gambar 1. Pengamatan karang Montipora sp yang terkena white syndrome dilakukan menggunakan bantuan alat skin diving dan underwater camera. Pengukuran koloni karang dilakukan menggunakan jangka sorong untuk mengetahui luasan koloni karang. Pengamatan dilakukan setiap 1 kali dalam 1 minggu dengan rentang waktu 7 hari sebanyak total 2 kali pengamatan untuk mengambil dokumentasi laju pertumbuhan penyakit white syndrome. Dokumentasi gambar yang diambil kemudian diolah menggunakan perangkat lunak ImageJ untuk mengukur luasan koloni karang, laju pertumbuhan penyakit $\left(\mathrm{m}^{2}\right)$, dan luasan bagian dead coral dan health coral. 


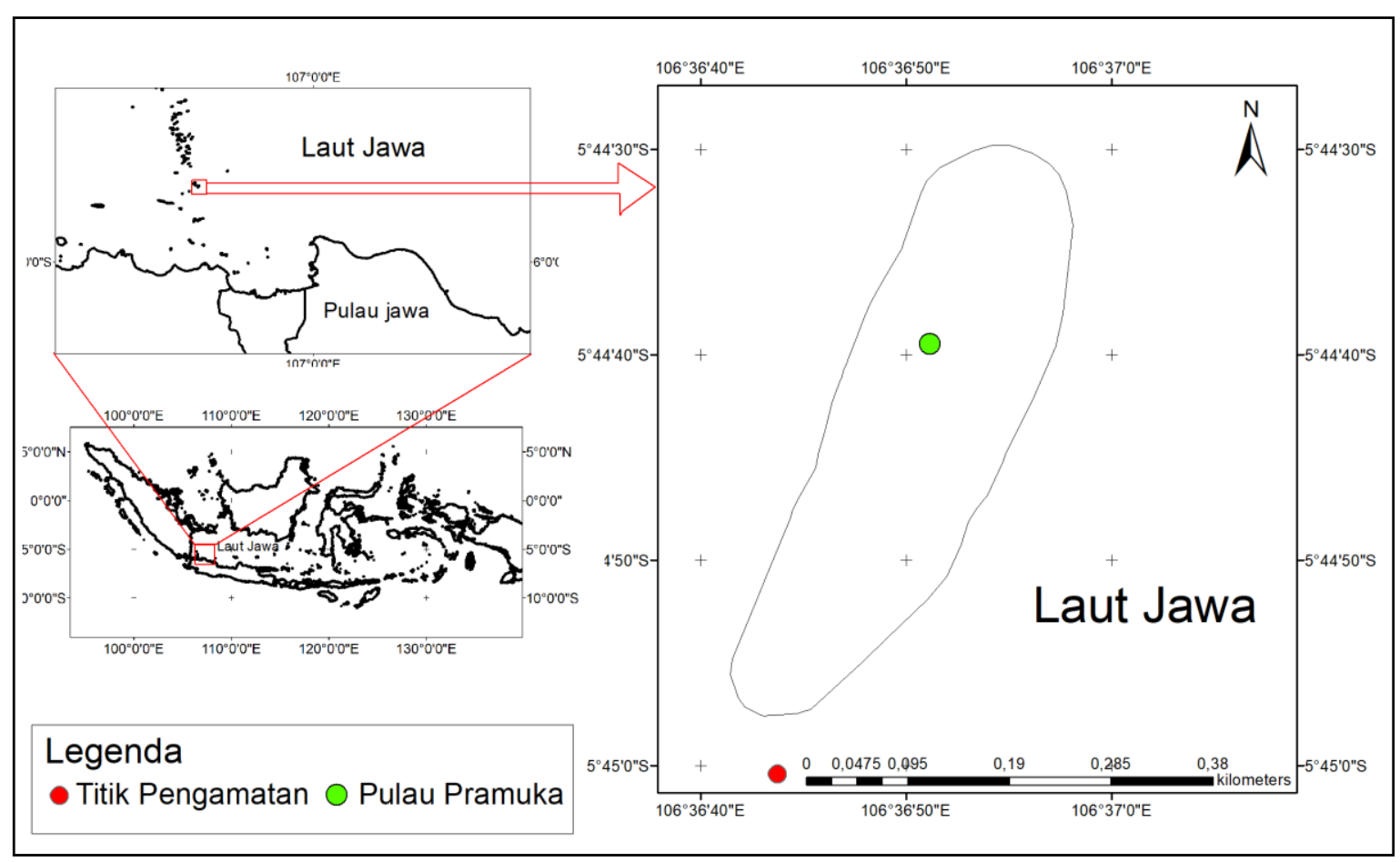

Gambar 1. Peta Lokasi Pengamatan di Pulau Pramuka.

ImageJ dapat digunakan untuk mengukur luasan dan persentase tutupan untuk analisis foto bawah air (van Woesik et al., 2009). Laju pertumbuhan penyakit linier diukur berdasarkan jarak terjauh perpindahan batas lesi (antara jaringan hidup dan mati). Laju pertumbuhan penyakit (luasan) diukur menggunakan ImageJ berdasarkan pertambahan luasan karang mati. Menurut Raymundo et al., (2008), laju pertumbuhan penyakit karang dapat diukur menggunakan rumus yang di tunjukkan persamaan 1.

Data parameter perairan menggunakan data sekunder berdasarkan Estradivari et al. (2009), yang mengamati terumbu karang jangka panjang (2003 - 2009). Parameter perairan yang diambil yaitu parameter suhu, arus, angin, gelombang, salinitas, dan curah hujan berdasarkan musim timur. Kecepatan angin pada musim barat yaitu 7 - $20 \mathrm{knot} / \mathrm{jam}$ dari arah barat daya sampai barat laut dan kecepatan angin pada musim timur $7-15$ knot/jam dari arah timur laut sampai tenggara. Pada bulan Mei - Oktober terjadi musim kemarau yang terkadang terjadi hujan yang berfrekuensi 4 10 hari/bulan dan bulan Agustus memiliki curah hujan terkecil. Arus di Kepulauan Seribu mengikuti pola hembusan angin. Pada bulan Mei September arah arus menuju barat dan puncak arus terjadi pada bulan Agustus. Gelombang pada musim timur berkisar antara 0,5 - 1,0 m. Suhu permukaan laut pada musim timur berkisar antara 28,5 - $31,0^{\circ} \mathrm{C}$. Salinitas di Kepulauan Seribu berkisar antara $30-34 \mathrm{ppm}$.

\section{Hasil dan Pembahasan}

\subsection{Deskripsi Lokasi}

Pulau Pramuka terletak di Kelurahan Pulau Panggang, Kabupaten Administrasi Kepulauan Seribu, DKI Jakarta, Indonesia. Pulau pramuka termasuk kedalam Seksi Pengelolaan Taman Nasional Wilayah III yang dikelola Balai Taman Nasional Kepulauan Seribu. Pulau Pramuka memiliki ekosistem terumbu karang, lamun, dan mangrove. Rata-rata tutupan karang hidup di Kepulauan Seribu berkisar adalah 33,1\% (Estradivari et al., 2009).

Penelitian ini dilakukan antara bulan Juli dan Agustus dengan kata lain terjadi musim timur di perairan Kepulaun Seribu (Agus et al., 2016). Pada

line progression rate: $\frac{\text { Distance from nail or cable to new disease front }}{\text { length of time of census (Days or Weeks or Months) }}$ 

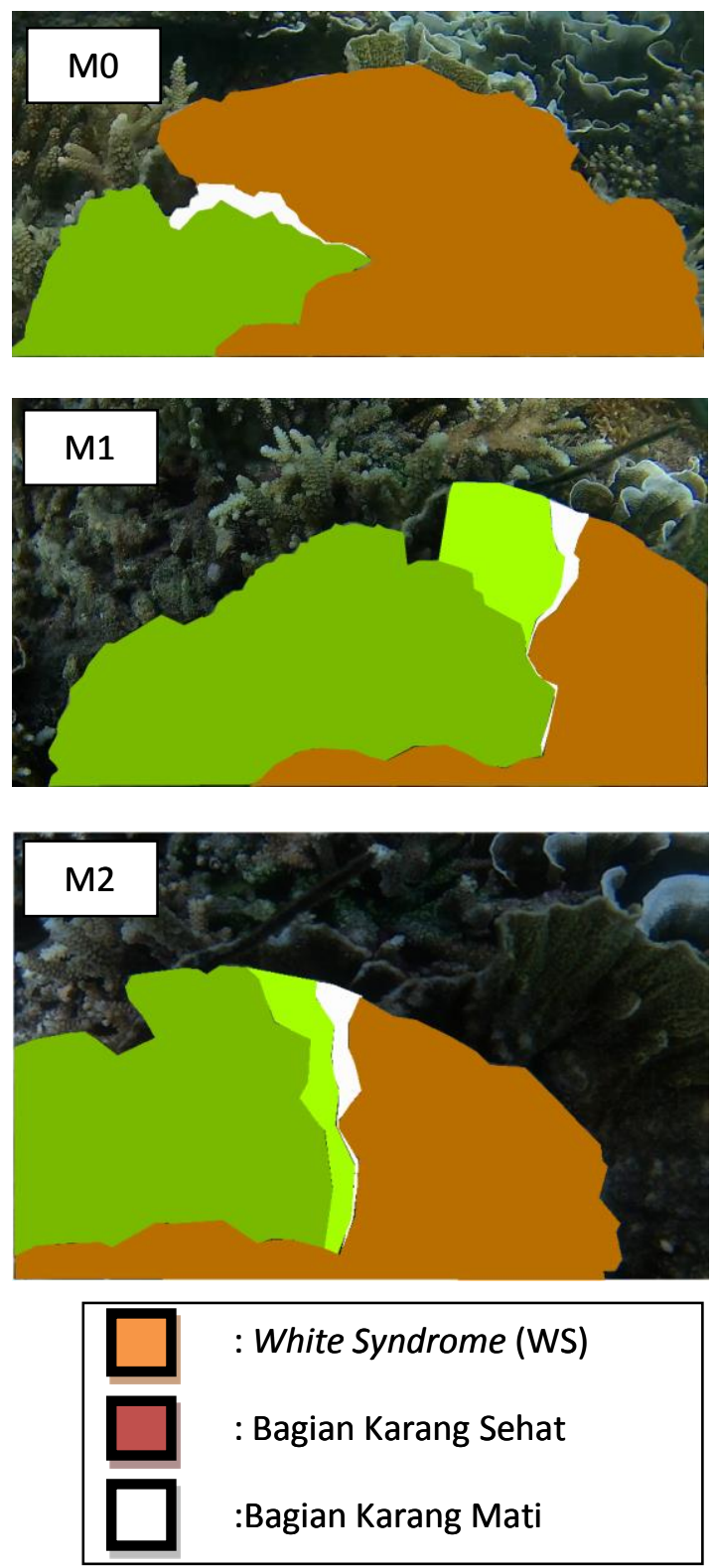
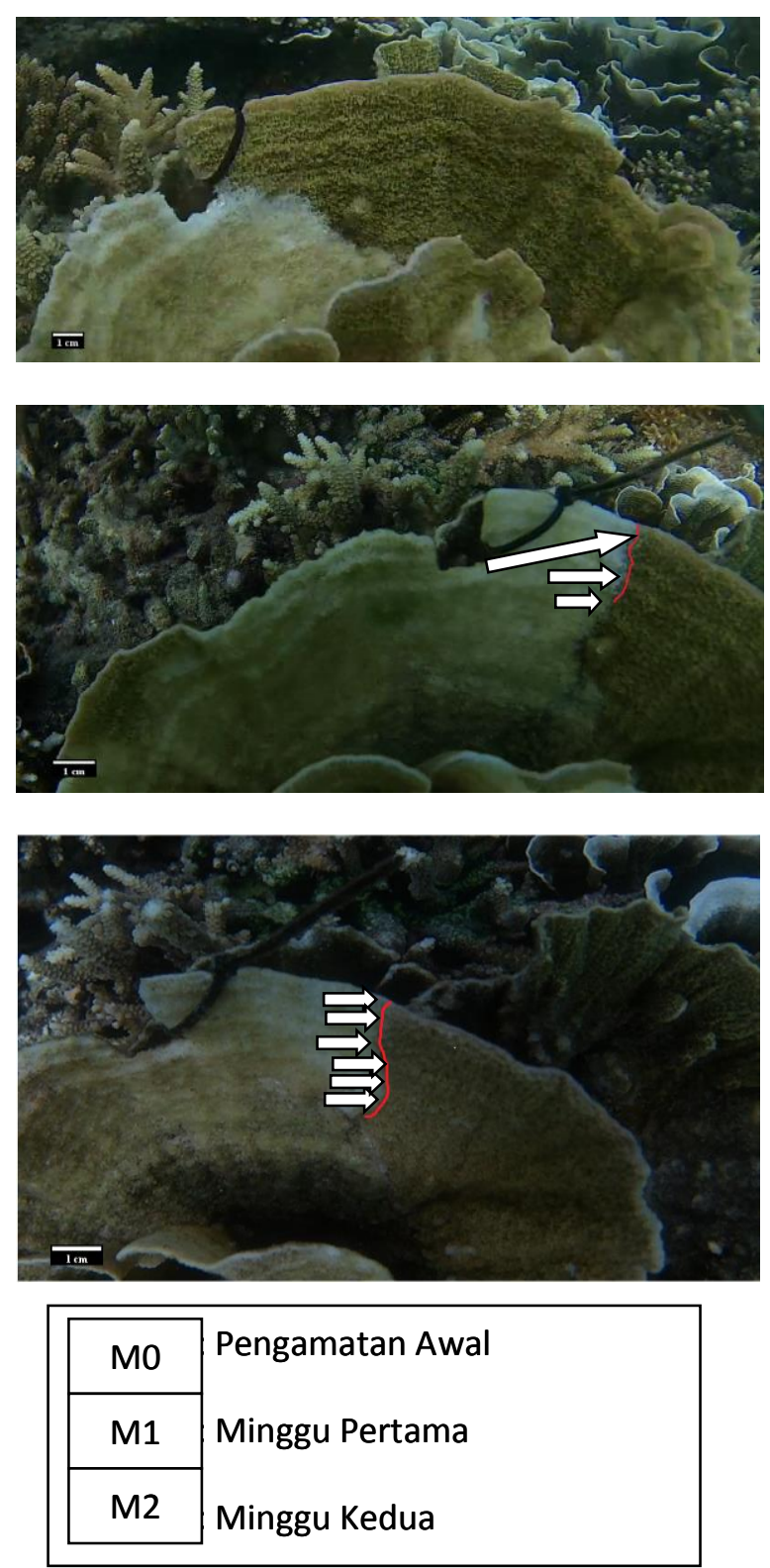

Gambar 2. Hasil Pengamatan Laju Infeksi White Syndrome pada Karang Jenis Montipora sp (Diolah Menggunakan Image J) Didapat Yaitu (A) Pengamatan Awal, (B) Pengamatan Minggu Pertama, dan (C) Pengamatan Minggu Kedua

musim timur kondisi angin di Kepulauan Seribu bergerak dari timur ke barat (Estradivari et al., 2009).

\subsection{Montipora sp.}

Montipora sp merupakan salah satu hewan penghasil terumbu yang berfotosintesis dengan zooxanthellae dan termasuk kedalam famili Acroporidae. Genus Montipora memiliki kerangka kapur yang koralitnya berukuran kecil $(<1 \mathrm{~mm})$. Montipora tidak memiliki columella dan memiliki conesteum yang lebar. Genus Montipora dengan bentuk pertumbuhan lembaran sering dijumpai mendominasi perairan dangkal. Bentuk pertumbuhan lembaran mampu menyerap intensitas matahari lebih banyak (Suharsono, 2008). Johan et al. (2011), melaporkan karang jenis Montipora merupakan jenis yang mendominasi perairan di Kepulauan Seribu.

\subsection{Laju Infeksi White Syndrome}

Penyakit White Syndrome yang ditemukan di perairan Pulau Pramuka menginfeksi karang Montipora sp. Penyakit white syndrome telah diamati juga oleh Johan et al., (2015) menginfeksi karang jenis Montipora sp. White syndrome terletak 
antara jaringan karang yang mati dan karang yang hidup.

Jenis penyakit white syndrome terkadang disebut juga sebagai Acroporid White Syndrome dikarenakan menginfeksi berbagai macam jenis dari Acroporaspp. Acropora cytherea, A. hyacinthus, A. clathrata, dan Acroporaspp. berbentuk tabulate adalah jenis-jenis karang yang paling banyak terkena infeksi penyakit white syndrome di wilayah Indo-Pasifik (Roff et al., 2011). Johan et al., (2015), melaporkan karang jenis Montipora spp dan Acropora spp banyak terinfeksi oleh penyakit white syndrome di perairan Kepulauan Seribu.

Menurut GBRMPA (2016), tingginya suhu perairan diikuti dengan tingginya prevalensi penyakit white syndrome yang menginfeksi karangkarang di Great Barrier Reef. Penyakit white syndrome juga dipengaruhi oleh limbah air laut dan sedimen yang dibawanya, hal tersebut juga mendukung bahwa ada kehadiran pathogen yang terikut dalam sedimen (Sheridan et al., 2013).

Laju infeksi pada Montipora sp yang telah diukur kemudian diolah menggunakan software ImageJ untuk mempermudah melihat luasan karang yang sehat, bagian karang yang mati, dan pergerakan dari WS. Luasan koloni karang yang terinfeksi dapat dilihat pada Gambar 2.

Laju linear dari infeksi white syndrome bervariasi antara $0-3.03 \mathrm{~cm} / \mathrm{minggu}$ pada koloni Montipora sp yang diamati pada penelitian ini. Luasan laju infeksi WS pada Montipora sp yang diukur pada minggu pertama didapatkan hasilnya sebesar $9.06 \mathrm{~cm}^{2}$ yaitu $9.34 \%$ dari bagian yang sehat dengan luasan WS sebesar $2.15 \mathrm{~cm}^{2}$. Laju infeksi WS pada minggu kedua sebesar $2.37 \mathrm{~cm}^{2}$ yaitu $2.69 \%$ dari bagian yang sehat dengan luasan WS sebesar $1.74 \mathrm{~cm}^{2}$. Penilitian yang dilakukan Roff et al. (2011), pada Acropora cytherea mendapatkan hasil laju infeksi linear dari WS berkisar antara $0-13.47 \mathrm{~cm} / \mathrm{minggu}$, sedangkan mortalitas jaringan pada Acropora sp yang disebabkan oleh WS mencapai $5.4 \%$ dalam satu minggu.

Penelitian yang dilakukan di Teluk Kane'ohe ditemukan penyakit white syndrome dengan prevalensi $<1 \%$ pada tahun 2007 (Aeby, 2007). Pada tahun 2010 penelitian yang dilakukan pada karang M. capitata di Teluk Kane'ohe terdapat wabah penyakit white syndrome dengan laju penyakit yang sangat cepat $>5 \mathrm{~cm}$ (Aeby et al 2010).
Penyebaran penyakit white syndrome tergolong sangat cepat. Penelitian yang dilakukan di Hawaii menemukan penyakit white syndrome pada Montipora pertama kali pada tahun 2003 (Aeby 2005). Pada tahun 2009 terjadi wabah white syndrome kronik di Hawaii (Ross et al., 2012). Wabah atau Outbreak menurut Raymundo et al. (2008), terjadi ketika $R_{0}>1$, dengan Ro merupakan rasio infeksi baru terhadap infeksi yang sudah ada. Menurut Aeby et al. (2010), laju penyakit terbagi menjadi 2 yaitu akut $(>5 \mathrm{~cm})$ dan kronis $(<5 \mathrm{~cm})$.

Faktor-faktor lain yang mempengaruhi laju infeksi penyakit WS pada terumbu karang adalah suhu. Roff et al. (2011), menemukan pada musim dingin laju infeksi WS meningkat dibandingkan musim panas dan koloni yang lebih besar memiliki mortalitas jaringan yang lebih besar.

\section{Simpulan}

Kesimpulan pada penelitian ini adalah mortalitas yang disebabkan oleh WS pada terumbu karang Montipora sp yang diamati mencapai $9.34 \%$ dengan laju penyebaran penyakit $9.06 \mathrm{~cm}^{2}$ (akut) pada minggu pertama dan $2.37 \mathrm{~cm}^{2}$ (kronis) pada minggu kedua. Pola penyebaran penyakit WS yang diamati sangat bervariasi atau tidak beraturan.

\section{Ucapan terimakasih}

Terimakasih kepada Seksi Pengelolaan Taman Nasional (SPTN) III Pulau Pramuka, Taman Nasional Laut Kepulauan Seribu, DKI Jakarta, yang telah memfasilitasi selama kegiatan penelitian disana.

\section{Daftar Pustaka}

Abrar, M., Bachtiar, I., \& Budiyanto, A. (2012). Struktur Komunitas dan Penyakit Pada Karang (Scleractinia) di Perairan Lembata, Nusa Tenggara Timur. ILMU KELAUTAN: Indonesian Journal of Marine Sciences, 17(2), 109-118.

Aeby, G. S. (2005). Outbreak of coral disease in the Northwestern Hawaiian Islands. Coral Reefs, 24(3), 481-481.

Aeby, G. S. (2007). Spatial and temporal patterns of Porites trematodiasis on the reefs of Kaneohe Bay, Oahu, Hawaii. Bulletin of Marine Science, 80(1), 209218.

Aeby, G. S., Ross, M., Williams, G. J., Lewis, T. D., \& Work, T. M. (2010). Disease dynamics of Montipora 
white syndrome within Kaneohe Bay, Oahu, Hawaii: distribution, seasonality, virulence, and transmissibility. Diseases of aquatic organisms, 91(1), 1-8.

Agus, S. B., Zulbainarni, N., Sunuddin, A., Subarno, T., Nugraha, A. H., Rahimah, I., Alamsyah, A., Rachmi, R., \& Jihad, J. (2016). Distribusi Spasial Rajungan (Portunus pelagicus) pada Musim Timur di Perairan Pulau Lancang, Kepulauan Seribu. Jurnal Ilmu Pertanian Indonesia, 21(3), 209-218.

Amanah, S. (2004). Perencanaan Strategis Pengelolaan Sumberdaya Pesisir Terpadu di Kelurahan Pulau Panggang Kecamatan Seribu Utara, Kabupaten Kepulauan Seribu Provinsi DKI Jakarta. Buletin Ekonomi Perikanan, 5(2), 1-16.

BPS DKI Jakarta. (2013). Statistik Daerah Ibukota DKI Jakarta 2013. Jakarta, Indonesia: Badan Pusat Statistik DKI Jakarta.

Bryant, D., Burke, L., McManus, J., \& Spalding, M. (1998) Reefs at risk: a map-based indicator of threats to the worlds coral reefs. New York, USA: World Resources Institute.

Chou, L. M. (2000). Southeast Asian Reefs-Status update: Cambodia, Indonesia, Malaysia, Philippines, Singapore, Thailand and Viet Nam. In Wilkinson, C. (Ed.). Status of Coral Reefs of the World: 2000. Townsville, Australia: Global Coral Reef Monitoring Network and Australian Institute of Marine Science, pp. 117-129.

Edinger, E. N., Jompa, J., Limmon, G. V., Widjatmoko, W., \& Risk, M. J. (1998). Reef degradation and coral biodiversity in Indonesia: effects of land-based pollution, destructive fishing practices and changes over time. Marine Pollution Bulletin, 36(8), 617-630.

GBRMPA (2016). Coral disease on the Great Barrier Reef. [online] Tersedia di: http://www.gbrmpa.gov.au/ managing-the-reef/threats-to-the-reef/climatechange/what-does-this-mean-for-species/corals/coraldisease/coral-disease-on-the-great-barrier-reef, [diakses: 29 September 2016].

Haapkylä, J., Unsworth, R. K., Seymour, A. S., Melbourne-Thomas, J., Flavell, M., Willis, B. L., \& Smith, D. J. (2009). Spatio-temporal coral disease dynamics in the Wakatobi Marine National Park, south-east Sulawesi, Indonesia. Diseases of Aquatic Organisms, 87(1-2), 105-115.

Johan, O., Bengen, D. G., Zamani, N. P., Suharsono, S., \& Sweet, M. J. (2015). The distribution and abundance of black band disease and white syndrome in Kepulauan Seribu, Indonesia. HAYATI Journal of Biosciences, 22(3), 105-112.

Miller, J., Muller, E., Rogers, C., Waara, R., Atkinson, A., Whelan, K. R. T., Patterson, M., \& Witcher, B. (2009). Coral disease following massive bleaching in 2005 causes $60 \%$ decline in coral cover on reefs in the US Virgin Islands. Coral Reefs, 28(4), 925.
Pandolfi, J. M., Bradbury, R. H., Sala, E., Hughes, T. P., Bjorndal, K. A., Cooke, R. G., McArdle, D., McClenachan, L., Newman, M. J. H., Paredes, G., Warner, R. R., \& Jackson, J. B. C. (2003). Global trajectories of the long-term decline of coral reef ecosystems. Science, 301(5635), 955-958.

Raymundo, L. J., Couch, C. S., Harvell, C. D., Raymundo, J., Bruckner, A. W., Work, T. M., Weil, E., Woodley, C. M., Jordan-dahlgren, E., Willis, B. L., \& Sato, Y. (2008). Coral Disease Handbook Guidelines for Assessment, Monitoring \& Management. Queensland, Australia: Coral Reef Targeted Research and Capacity Building for Management Program, Centre for Marine Studies, University of Queensland.

Rochyatun, E., \& Rozak, A. (2007). Pemantauan kadar logam berat dalam sedimen di perairan Teluk Jakarta. Makara Journal of Science, 11(1), 28-36.

Roff, G., Kvennefors, E. C. E., Fine, M., Ortiz, J., Davy, J. E., \& Hoegh-Guldberg, O. (2011). The ecology of 'Acroporid white syndrome', a coral disease from the southern Great Barrier Reef. PLoS One, 6(12), e26829.

Ross, M., Stender, Y., White, D., \& Aeby, G. S. (2012). Outbreak of the coral disease, Montipora White Syndrome in Maui, Hawai ' $i$. In Proceedings of the 12th International Coral Reef Symposium. Cairns, Queensland, Australia, 9-13 July 2012 (pp. 9-13).

Estradivari, E., Setyawan, E., \& Yusri, S. (2009). Terumbu Karang Jakarta: Pengamatan Jangka Panjang Terumbu Karang Kepulauan Seribu (2003-2007). Jakarta, Indonesia: Yayasan Terumbu Karang Indonesia (TERANGI).

Sheridan, C., Kramarsky-Winter, E., Sweet, M., Kushmaro, A., \& Leal, M. C. (2013). Diseases in coral aquaculture: causes, implications and preventions. Aquaculture, 396, 124-135.

Soenardjo, N. (2013). Karakterisasi Bakteri yang Berasosiasi dengan Penyakit Pink-Blotchdi P. Sambangan, Karimunjawa. Buletin Oseanografi Marina, 2(1), 58-65.

Suharsono, S. (2008). Jenis-jenis Karang Indonesia. Jakarta, Indonesia: LIPI Press

Ushijima, B., Smith, A., Aeby, G. S., \& Callahan, S. M. (2012). Vibrio owensii induces the tissue loss disease Montipora white syndrome in the Hawaiian reef coral Montipora capitata. PloS one, 7(10), e46717.

Ushijima, B., Videau, P., Burger, A. H., Shore-Maggio, A. Runyon, C. M., Sudek, M., Aeby, G. S., \& Callahan, S. M. (2014). Vibrio coralliilyticus strain OCN008 is an etiological agent of acute Montipora white syndrome. Applied and Environmental Microbiology, 80(7), 21022109.

van Woesik, R., Gilner, J., \& Hooten, A. J. (2009). Standard operating procedures for repeated measures of process and state variables of coral reef 
environments. Queensland, Australia: Coral Reef Targeted Research and Capacity Building for
Management Program, Centre for Marine Studies, University of Queensland.

(C) 2018 by the authors; licensee Udayana University, Indonesia. This article is an open access article distributed under the terms and conditions of the Creative Commons Attribution license (http://creativecommons.org/licenses/by/3.0/). 